
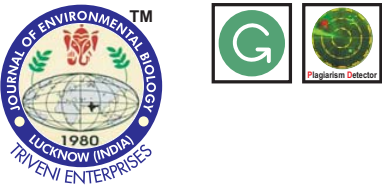

\title{
Indigenous technical knowledge in little millet cultivation among "Malayali" tribes of India
}

\section{Authors Info \\ P. Venkatesan ${ }^{1 *}$ and M. Sundaramari ${ }^{2}$ \\ ${ }^{1}$ Extension Systems Management Division, ICAR-National Academy of Agricultural Research Management, Hyderabad- 500 030, India \\ ${ }^{2}$ Faculty of Agriculture, A.H., Gandhigram Rural Institute, Gandhigram, Dindigul- 624 302, India}

${ }^{*}$ Corresponding Author Email : venkatesan@naarm.ernet.in

Key words

Adoption Indigenous knowledge Millet cultivation Sustainable agriculture

Publication Info Paper received : 27.10 .2016 Revised received : 23.12 .2016 Re-revised received : 02.03 .2017 Accepted:09.03.2017

\section{Abstract}

Aim: Indigenous Tribal Agricultural Practices (ITAPs) has potential to significantly raise the production and sustain it in the long run. These ITAPs have more adaptability to the local situation, and hence can be used in formal advisory system. Several such useful ITAPs existent at field level is at the brink of total disappearance. Hence in the present study, the selected ITAPs of little millet were examined for their rationality and extent of adoption.

Methodology: The indigenous knowledge in little millet were aggregated, categorized and reported. The selected ITAPs of little millet were examined for their rationality.For assessing the rationality, twenty three ITAPs were bifurcated viz., nineteen related to crop production and four related to plant protection aspects. Further, the extent of adoption by the tribal farmers were analyzed.

Results: From the selected twenty three ITAPs of little millet, nineteen $(82.60 \%)$ were rational and four $(17.40 \%)$ were irrational. Sixteen ITAPs were adopted by $75 \%$ of farmers (fourteen of them were rational and two of them were irrational), six ITAPs were adopted by $50-75 \%$ of the respondents (five of them were rational and one was irrational) and only one ITAP was found to be irrational with low adoption $(<50 \%)$.

Interpretation: The rational and effective ITAPs can be incorporated into existing efforts to enhance and expand effectiveness and can also serve as the basis for new initiatives.

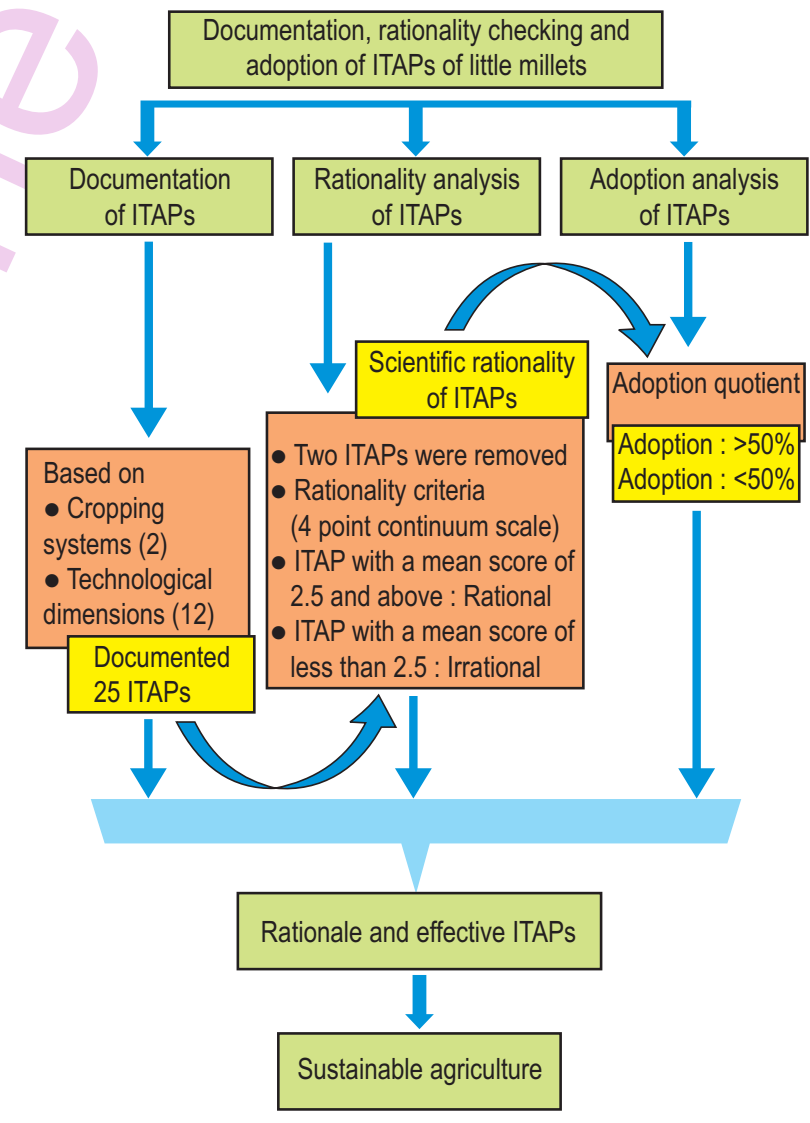




\section{Introduction}

Tamil Nadu in India, with its long history had been a cradle of biological wealth, intellectual knowledge and spiritual wisdom. The tribal communities have long met many challenges of nature by drawing on their local environments, inventing effective agricultural techniques, and learning the medicinal and nutritional value of nearby plants. Harsh conditions have done as much to induce individual creativity and innovation as to benefit them. At the same time, such local knowledge, is in danger of extinction in tribal belt (Singh et al., 2015), with the rise of modern technologies and the drastic change being visualized in all spheres of Indian life by the process of globalization. Further traditionally strong links existing between grandparents and grandchildren have been weakening as mobility escalated. The indigenous knowledge is the information secured over a period and progressed from generation to generation by the word of mouth (Suresh, 2010).

Likewise, the Malayali tribes, the inhabitants of Kolli Hills, migrants from Kancheepuram area of Tamil Nadu during 1960s (Vaidyanathan et al., 2013) are bowl of indigenous knowledge. They initially cleared the forest area and cultivated food crops, predominately 21 races of millets for their self-sufficient subsistence economy (Venkatesan et al., 2015). They have been dependent on the utilization of various natural resources including the plant species at least until last twenty years. Their isolation from the main currents of Indian life had helped the tribes in preserving their rich ITAPs. Farming is the predominant occupation of the Malayali tribe, who sustain their livelihoods by application of ITAPs to maximize production for generations. Instead of collecting information on indigenous knowledge from individuals, interaction with groups (focused group discussion) paved way for easy documentation and triangulation (Rathakrishnan et al., 2009). Many farmers recognize and appreciate the value of growing their native crop varieties in a traditional way. However, any practice should have a scientific background before being disseminated to others, hence testing the rationality analyses of ITAPs is essential. "Rationality" refers to the practices that are accountable with scientific reasons or confirmed based on long time experience. Whereas, "Irrationality" refers to the practices, which cannot be scientifically hypothesized or confirmed with long time experience (Sakeer Husain and Sundaramari, 2010). Moreover, the plant genetic resources of minor millets are need of hour to enhance resilience of local production systems through nutrition security. Millets is crop, which can adapt to edaphic and climate stresses replacing wheat and rice (Chandel et al., 2014). These qualities do strength and opportunity of nutritional sensitive agriculture with enhanced income.

Keeping this in view, the present study was formulated to aggregate, categorize, examine and rationalize the ITAPs of little millets in Kolli Hills of Tamil Nadu.

\section{Materials and Methods}

The study was executed in Kolli Hills, Tamil Nadu, India (the tail end of the Eastern Ghats in the state) with an area of 441 sq. $\mathrm{km}$. The hills of Kolli hills were with deep ravines and high peaks. The mean annual temperature of Kolli hills is $14^{\circ} \mathrm{C}$ to $28^{\circ} \mathrm{C}$. This area receives an average annual rainfall of $1440 \mathrm{~mm}$. The hill is predominant with two type of soil i.e. top most hill area with sandy loam soil and the bottom of the valley characterized by alluvial and clay loam soil.

In Kolli hills of Namakkal district, the group of $10-15$ hamlets villages ('oor') constituted into a cluster of villages ('nadu'). In this study 14 clusters of villages were selected using simple random sampling based on net cultivated area. The data was collected in three phases, starting from documentation, rationality analysis to determination of extent of adoption of ITAPs on little millet.

For the first phase of the study, twenty old aged $(>65$ years) and experienced farmers ( $>45$ years) were selected from each of the sampled villages and the ITAPs of little millet were collected through key informant interviews. Thus, a total of one hundred forty farmers were interviewed for generating primary data on ITAPs. A total of twenty-five ITAPs were collected and classified systematically based on the two identified cropping systems (upland and rocky undulated terrain) and with twelve technological dimensions.

In the second phase, after deleting the cluster specific practices, twenty-three ITAPs of little millet were selected for further analysis. Fifty scientists with more three years' of working experience in little millet were randomly chosen from State Agricultural Universities and Central Universities in India. The expert scientific assessment was obtained through agricultural scientist through two closed ended questionnaires, one containing ITAPs related to crop production aspects (nineteen ITAPs) and second having ITAPs related to crop protection aspects (four ITAPs). The rationality was assessed using fourpoint rating scale (1- Irrational based on scientific evidence, 2Irrational based on experience, 3- Rational based on experience, 4- Rational based on scientific evidence). The total score of the specific ITAP was calculated based on the mean score (Table.1). The ITAPs were categorized into two, based on their mean score. ITAPs with a mean score of 2.5 and above were categorized as a

Table 1 : Scoring procedure to assess the rationality of indigenous technologies

\begin{tabular}{ll}
\hline Responses & Scores \\
\hline Rational based on scientific evidence & 4 \\
Rational based on experience & 3 \\
Irrational based on experience & 2 \\
Irrational based on scientific evidence & 1 \\
\hline
\end{tabular}


"rational" and with a mean score below 2.5 as "irrational" (Sakeer Husain and Sundaramari ,2010).

During the third phase, thirty little millet cultivating farmers were selected using proportionate random sampling and a structured interview schedule was administered to assess their extent of adoption of ITAPs in little millet. The selected ITAPs were explained to the respondents and were asked to indicate if they had adopted the practice at least once in the past three years. The score of one and zero were assigned to the answers 'Yes' and 'No' respectively. The individual adoption score was calculated by summing up the score obtained for all the ITAP practices of little millet (Sundaramari and Ranganathan,2003).

\section{Results and Discussion}

In the present study, rationality was categorized into two i.e., rational and irrational. The ITAPs which were accountable with scientific reasons, or confirmed based on long time experience were categorized as 'rational'. One which were not scientifically hypothesized, or confirm with long time experience were denoted as 'irrational'. The rationality of a ITAPs was worked out, based on the mean score given by the scientists to individual ITAP. ITAPs with a mean score of 2.5 and above was considered as a rational and with ITAPs with a mean score of less than 2.5 were considered as irrational. Further the selected ITAPs with their rationality score was verified towards extent of adoption by the tribal farmer respondents.

Nineteen ITAPs and four ITAPs were selected from crop production and plant protection aspects respectively. In the plant protection aspect all the ITAPs were rational, where as in crop production, fifteen ITAPs were rational and four ITAPs were found to be irrational. All together sixteen ITAPs (fourteen ITAPs: rational and two ITAPs: irrational), six ITAPs (five ITAPs: rational and one ITAP: irrational) and one ITAP (ITAP 7: irrational) were adopted by more than $75 \%, 50-75 \%$ and less than $50 \%$ of the farmers respectively (Table.2).

The extent of adoption of twenty-two ITAPs on little millet cultivation was more than $50 \%$ adoption except one ITAP (ITAP 7). Thus the practice wise adoption was significantly high i.e., $95.65 \%$ adoption, by more than $50 \%$ of the respondents.

Kolli hills tribal farmers cultivated local races of little millet viz., Karumsamai (73.33\%), Malliyasamai (70.00\%), Saddansamai (76.67\%), Thirikulasamai (90.00\%), Vellamperumsamai (90.00\%) and Vellasamai (40.00\%) (Fig.AG). Karumsamai was grown for 5-6 months from May/June to September/October or December/January and Malliyasamai was grown for three month from June to August. Saddansamai, Thirikulasamai and Vellasamai were grown from May/June to September/October, whereas the Vellamperumsamai was long duration cultivar grown from June to January. Thirikulasamai and
Vellamperumsamai varieties of the study area were suitable for rainfed areas. The later one is resistant to lodging and multi tillering in nature. The striking traits in these races are its resistivity to foot rot and shoot fly with high nutritional quality (33 ppm Fe, $32.00 \mathrm{ppm} \mathrm{Zn}$ and $9-10.50 \%$ of protein), taste and ability to provide yield in water deficit conditions.

The farmers $(83.33 \%)$ cultivate little millet in upland where ash soil ( $\mathrm{pH}-5.0$ to 5.5) (Fig. H) with low water holding capacity is found, which is scientifically proven with the rationality of 3.37. This soil is modified form of red soil, clay content is minimum (clay fractions of these soils are dominated by 1:1 clays and aluminum and iron oxides), but rich in organic matter content, rich in fertility and medium to low water holding capacity (Sharma et al.,2015). The soil becomes hard during water deficit conditions and the tribal expressed that little millet could survive in this harsh condition. Likewise, the Saddansamai cultivar performed well as a pure crop in terraced field with the scientific rationale of 2.65 and with $76.67 \%$ adoption by the respondents.

In the preparatory phase of main land preparation, the farmers $(83.33 \%)$ tilled the land for 2-3 times using country plough. In the uplands, this type of conventional tillage with wooden plough is being followed. The first plough starts after the first rain. This is done across the slope to reduce the soil hardness and to hold more rainwater. Thus this practice has a scientific rationality of 3.28 . The farmers $(80.00 \%)$ incorporated the crop residues and stubbles in soil for digestion, as this practice helps in soil and water conservation(3.72R).

The seeds were treated with a mixture of ash and cow dung $((76.67 \%)$. This helped in absorbing excessive moisture, thereby preventing entry of pests for feeding or laying eggs on seeds during sprouting stage. Moreover, the use of cow dung helps to bind ash on seeds, breaks dormancy and improve germination (Mathad et al., 2013). Seeds were then dried and broadcasted by hand for small acreage; they can be sown immediately and then covered with soil. About $63.33 \%$ of the respondents broadcasted the seeds of little millet @12-15 kg ha ${ }^{-1}$ for early maturity and 7-8 kg ha $^{-1}$ for late maturing genotypes (Table.2).

The farmer respondents (73.33\%) used pseudo stem of banana or secondary branches of the trees to cover the broadcasted seeds with soil. This practice had a scientific rationale of 3.72 as it ensured adequate soil covering of broadcasted seeds at a desirable depth. Cross ploughing is a second ploughing carried out (66.67\%) after 10-15 days of crop emergence using country wooden plough. The cross ploughing is performed from different direction, usually at right angles from that of first ploughing. Cross ploughing helps in weed control, thinning of plants and conserve moisture (Priyanka et al., 2013).

Tribal farmers $(80.00 \%)$ followed the mixed cropping system to ensure better cropping intensity. Ittle millet was mixed 
Table 2 : Rationality and adoption of ITAPs on little millet cultivation

Rationality \% of score adoption

\section{A. Crop production}

Duration of local landrace of little millet namely, Karumsamai is 5 to 6 months (May/June to September/October) or (May/June to December/January) with a seed rate of $18-20 \mathrm{~kg} / \mathrm{ha}$, fetching a yield of $2000 \mathrm{~kg} / \mathrm{ha}$. The main character of Karumsamai is having multitiller, loose panicle, straw is palatable to cattle, susceptible to lodging during rainy season.

Local landrace of little millet namely, Malliyasamai is a three months duration cultivar (June-November), with no tillers, slender stem and cultivated as a pure crop, but susceptible to rains during maturity stage. It is having a pinkish pigmentation at nodal area of the stem, with pale brown grains. Local landrace of little millet namely, Saddansamai performs well in the season of June-October. It is a non tillering race cultivated as pure crop in terraced fields.

Local landrace of little millet namely, Saddansamaiis mostly grown for straw pupose, used as a thatching material and dry fodder for cattle. It is tolerant to flood, with good taste.

Pounding of local landrace of little millet namely, Saddansamai is difficult as compared to Malliyasamai. Local landrace of little millet namely, Thirikulasamai is grown in the season of June-September. This little millet is multi-tillering, sown with wider spacing for better yield, short duration and grown as pure crop in the dry lands. Local landrace of little millet namely, Vellamperumsamai performs well in the season of June-January. This little millet is of long duration, resistant to lodging \& multi tillering.

Vellasamai is organically grown with the seed rate of $75 \mathrm{~kg} / \mathrm{h}$ a with a duration of 4 months (May/June to September), and a yield of $2000 \mathrm{~kg} / \mathrm{ha}$. Little millet is grown in ash soil (Sambalmann).

Little millet is followed by mixed cropping of fox tail millet and tapioca as crop rotation in December- January. Little millet is grown in uplands (mettukadu) with low water holding capacity characterized by sandy soil in terrace cultivation.

Tilling the land 2 to 3 times using country plough.

Seeds are broadcasted after ploughing, $12-15 \mathrm{~kg} \mathrm{ha}^{-1}$ (early maturity) and 7 to $8 \mathrm{~kg} \mathrm{ha}^{-1}$ (late maturity). Incorporation of crop residues, stubbles \& digested residues of hedges grown on the bunds.

Pseudo stem of banana or secondary branches of the trees to cover the seeds with soil and it ensured adequate soil covering of broadcasted seeds at a desirable depth.

Cross ploughing is carried out after 10-15 days of crop emergence using country wooden plough with the objectives of controlling weeds, thinning of plants and moisture conservation in a single operation. In long duration, little millet panicle alone is harvested and threshed by beating with sticks. In short duration the whole plants are harvested near the ground level using sickle and threshed on the threshing floor by trampling using bullock.

Hardiness of the grains is tested by biting them or by threshing whole debraned grain between fingers on any surface.

Entire earhead of little millet with well-formed grains are selected during the harvest and kept aside as seed material.

\section{B. Crop protection}

Treating the little millet seeds before sowing with a mixture of ash and cow dung effectively prevents the attack by pests and diseases.

Dusting of ash over the crops at the rate of $45-50 \mathrm{~kg} / \mathrm{ha}$

$5 \mathrm{~kg}$ of Lantana camera leaves are soaked in 5 lit of cow urine for 3 days. This is then diluted in 90 lit of water and sprayed against fungal diseases.

Sun drying is done to dry grains, usually on a new moon day reduces the risk of damage by storage pest.

cropped with fox tail millet (Setariaitalica (L.) P. Beauv.) (Fig. I) and followed by Cassava (Manihotesculenta Crantz) in December- January, as crop rotation, with scientific rationality of 3.05 R. The mixed cropping of little millet with fox tail millet ensures food security in the event of monsoon failure and increases the returns from the land. This mixed cropping system is similar to "Akkad" cropping followed in Karnataka (Ramachandrappa et al., 2016), which was found to be an effective water conservation system under rainfed conditions.
Rotating a food security crop of little millet with cash crop like cassava ensures income for the farmers.

About $45-50 \mathrm{~kg} \mathrm{ha}^{-1}$ of ash was dusted to control the menace of sucking pest in little millet $(2.60 \mathrm{R})$ (Sharma and Ortiz,2002). Lantana camara leaves ( $5 \mathrm{~kg}$ ) soaked in cow urine (5I) for 3 days and diluted in 90 I of water was sprayed by $93.33 \%$ of the respondents against fungal diseases. Deepika Srivastava and Padma Singh (2011) reported that Lantana camara exhibits 

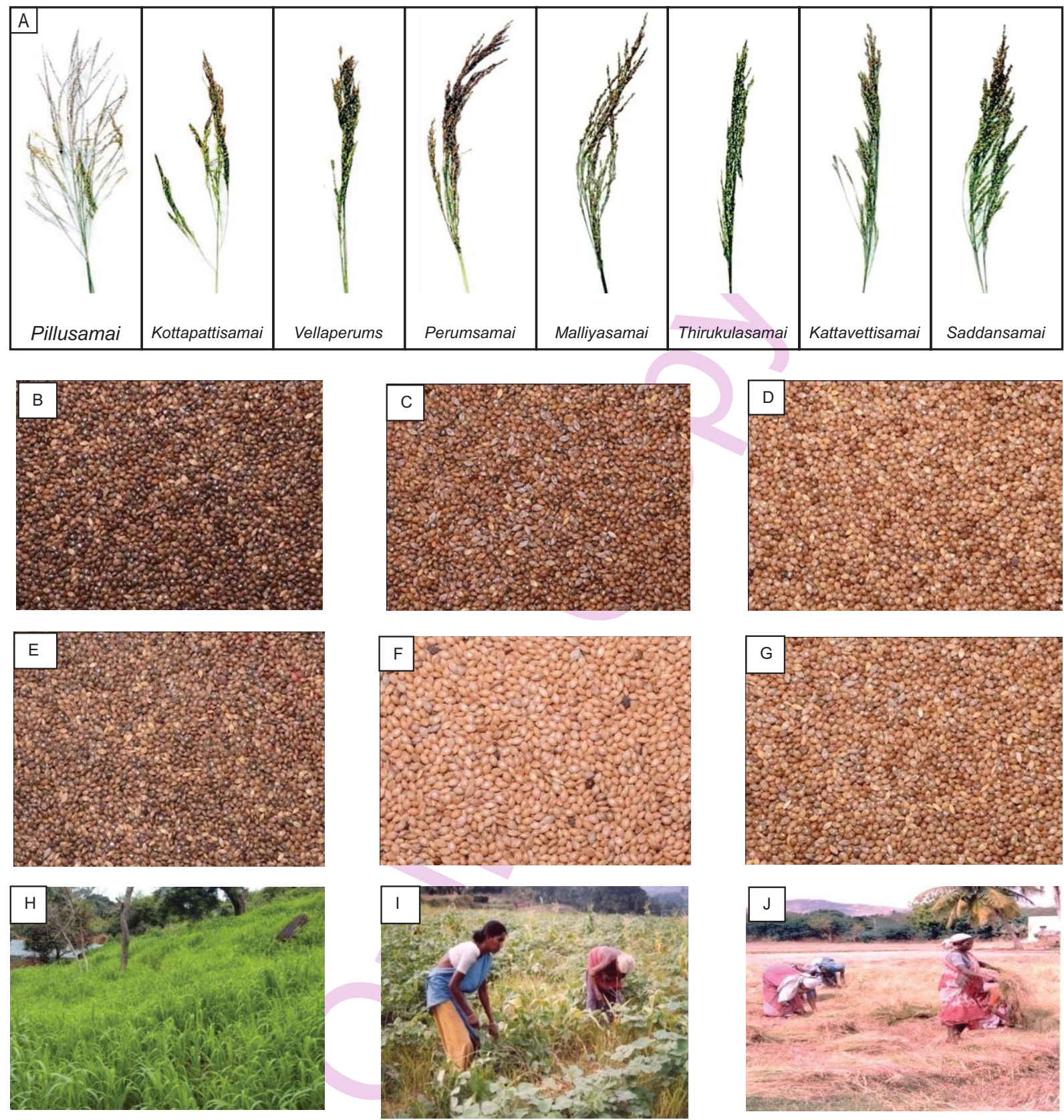

Fig. 1 : (A) Ear heads of Indigenous Little Millet; (B) Karumsamai seeds; (C) Malliyasamai seeds; (D) Saddansamai seeds; (E) Thirukulasamai seeds; (F) Vellaperumsamai seeds; (G) Vellasamai Seeds; (H) Little millet grown in upland; (I) Mixed cropping; (J) Harvesting of whole plant of little millet at the ground level

antifungal properties. Cow urine possess complex degrading substances and inhibits a number phytopathogenic bacteria and fungi (Basaket al., 2002a; Basak et al., 2002b; Akhter et al., 2006; Rakesh etal., 2013).

In the case of long duration little millet only the panicle of the crop was harvested ( $83.33 \%$ ), whereas the whole plant was harvested using sickle in short duration crop (Fig. J). After harvest, little millet is sun- dried on a new moon day before storage $(73.33 \%)$ and had a rationality score of 2.61 as this reduces the damage of storage pests. This process was done to avoid decrease in germination capacity and to reduce the moisture content up to $10 \%$. Scientifically, the seeds should be dried under the sun between 8 a.m. to 12 noon and then 3 p.m. to 5 . p.m. 
The matured earhead with well-formed grains of little millet were kept aside as seed materials. This practice was followed by $86.67 \%$ of the respondents and was also found as rational with the scoring of 3.27 , as selection of healthy seed material is always important in cultivation process. Since many farmers keep their own millet seed which is invariably a mixture of local cultivars, they exercise care and select uniform ears and preserve them as seed for the next season. Farmers select the best heads in field, cut them, dry and store them separately in long strawed bundles. This exercise helps farmers to carry forward varieties of millet that they feel to be superior and of higher quality.

With the age old experience, $93.33 \%$ of the respondents tested hardiness of the grains by biting them or by threshing whole debraned grains between fingers on any surface. Because moisture content of the grain should be $15-18 \%$. At this moisture content, there will be less mechanical damage and seed injury. If the moisture content is more or less than 15 to $18 \%$ during threshing, seed injury will occur. At high moisture, the seed injury leads to fast deterioration of seed quality favouring fungal infection. The above finding derives research support from that of Bhag Mal et al.(2010) and Adikant Pradhan et al. (2010).

The Malyali tribe of Kolli Hills has nurtured several ITAPs oflittle millet over the years and perfected them to suit the agroclimatic and soil conditions. This research work has identified effective and scientifically rational ITAPs, which should be recommended and disseminated by the extension functionaries in other areas.

\section{Acknowledgment}

Authors are thankful to the farmers of Kolli hills for sharing their valuable in-depth indigenous knowledge on the cultivation practices of little millet.

\section{References}

Adikant, P., S.K. Nag and S.K. Patil: Traditional technique of harvesting and processing for small millets in tribal region of Bastar. Ind. J. Trad. Know., 9, 681-683 (2010).

Akhter, N., M.F. Begum, S. Alam and M.S. Alam: Inhibitory effect of different plant extracts, cow dung and cow urine on conidial germination of Bipolaris sorokiniana. J. Bio. Sci., 14, 18-92 (2006).

Basak, A.B. and T.S. Lee: Inhibitive activity of cow urine and cow dung against Sclerotina sclerotium of cucumber. Mycobiology, 30, 175179 (2002a).

Basak, A.B. and T.S. Lee: In vitro inhibitory activity of cow urine and cow dung against Fusarium solani.f. sp of cucurbitae. Mycobiology, 30 , 51-54 (2002b).
Chandel, G., R.K. Meena, M. Dubey and M. Kumar: Nutritional properties of minor millets: Neglected cereals with potentials to combat malnutrition. Curr. Sci., 107, 1109-1111(2014).

Priyanka, G., B. Lal, J.L. Katara and J. Ekta: Beushening: A traditional method of rice crop establishment in Eastern India. Popular Kheti, 1,1 (2013).

Mal, B., S. Padulosi and S. Bala Ravi: Minor millets in South AsiaLearning from IFAD-NUS Project in India and Nepal. Biodiversity International, Italy (2010).

Mathad, R.C., S.N. Vasudevan, N.C. Mathad and S.B.. Patil: Traditional seed treatment and storage methods of Northeastern region of Karnataka. AsianAgri-History, 17, 233-239(2003).

Rakesh, K.N., N. Dileep, N.A.S. Nawaz, S. Junaid and P.T.R. Kekuda: Antifungal activity of cow urine against fungal pathogens causing rhizome rot in ginger. Environ. Eco., 31, 1241-1244 (2013).

Ramachandrappa, B.K., M.N. Thimmegowda, A. Sathish, B.N. Jagadeesh, K. Devaraja, P.N. Srikanthbabu and M.S. Savitha: Real time contingency measures to cope with rainfall variability in Southern Karnataka. Indian J. Dryland Agric. Res. Dev., 31, 37-43 (2016).

Rathakrishnan. T., M. Ramasubramanian, N. Anandaraja, N. Suganthi and S. Anitha: Traditional fishing practices followed by fisher folks of Tamil Nadu. Ind. J. Trad. Know., 8, 543-547 (2009).

SakeerHusain, A. and M. Sundaramari: Scientific rationality and evaluation on indigenous plant protection practices on coconut. $J$. Plantn.Crops, 39, 290-298 (2010).

Sharma. H.C. and R. Ortiz: Host plant resistance to insects: An ecofriendly approach for pest management and environment conservation. J. Environ. Biol., 36, 241-247 (2015).

Sharma, V.K., R.N. Pandey and B.M. Sharma: Studies on long term impact of STCR based integrated fertilizer use on pearl millet (Pennisetum glaucum)- wheat (Triticum aestivum) cropping system in semi-arid condition of India. J. Environ. Biol., 23, 111-135 (2002).

Srivastava, D. and P. Singh: Antifungal potential of two common weeds against plant pathogenic fungi- Alternaria sps. Asi. J. Exp. Biol. Sci., 2, 525-528 (2011).

Singh, A.K., A.Pedapati and Manibhushan: Assessment of exchange of crop in view of change climate and international treaties. $J$. Environ. Biol., 36, 309-317 (2015).

Sundaramari. M. and T.T. Ranganathan: Indigenous agricultural practices for sustainable farming. Agrobios (India) Publishers, Jodhpur, India (2003).

Suresh, K.P.: Indigenous agricultural practices among Mavilan tribe in North Kerala. Study Tribes Tribals, 8, 103-106(2010).

Vaidyanathan, D., M.S. Salai, S. Kumar, N. Sisubalan and M.G. Basha: Studies on ethnomedicinal plants used by Malayali Gounder Tribes in Pachamalai of Eastern Ghats, Tamil Nadu, India. Advn. Appl. Sci. Res., 5, 244-253(2013).

Venkatesan, P., M. Sundaramari and R.V. Kumar: Ethnotaxonomical classification of little millet (Panicum sumatense) by tribal people in Tamilnadu, India. Eco. Env. Cons., 21, 215-222 (2015). 